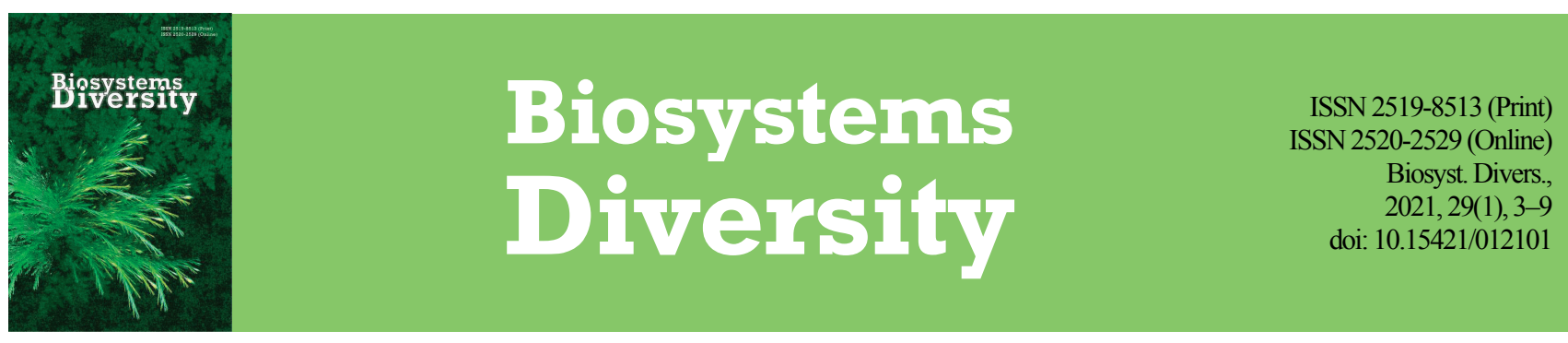

\title{
Effects of fires on vascular plant and microalgae communities of steppe ecosystems
}

\author{
V. V. Shcherbyna*, I. A. Maltseva**, H. V. Maltseva**, O. V. Zhukov** \\ *Dmytro Motornyi Tavria State Agrotechnological University, Melitopol, Ukraine \\ **Bogdan Khmelnitsky Melitopol State Pedagogical University, Melitopol, Ukraine
}

Article info

Received 14.01.2021

Received in revised form 11.02.2021

Accepted 12.02.2021

Dimytro Motornyi

Tavria State

Agrotechnological

University, Khmelnytsk

$a v$,

18 B, Melitopol,

72312, Ukraine

Tel.: + 38-98-507-96-82

E-mail: valentyna.

shcherbina

(atsatu.edu.ua

Bogdan Khmelnitsk

Melitopol State

Pedagogical University

Hetmanska st., 20

Melitopol, 72318, Ukraine

$\mathrm{Tel} \cdot+38-096-548-34-36$

E-mail:

maltseva_irina@ukr.net
Shcherbyna, V. V., Maltseva, I. A., Maltseva, H. V., \& Zhukov, O. V. (2021). Effects of fires on vascular plant and microalgae communities of steppe ecosystems. Biosystems Diversity, 29(1), 3-9. doi:10.15421/012101

The article is focused on a hypothesis verification: the higher plants, microalgae and cyanobacteria may be used in bioindication of steppe ecosystem restoration dynamics after fires. On the territory of the Askania Nova biosphere reserve (Ukraine) 4 stationary polygons were investigated: SP1 - steppe area which had not been exposed to fire for 20 years preceding our study, as well as areas where single fires occurred in 2001 (SP2), 2005 (SP3), and a site where fires occurred in 2001 and 2004 (SP4). The investigation revealed the dynamics of height and projected area of the higher vegetation according to seasons during two years (2010 and 2011), as well as abundance and biomass of microalgae and cyanoprokaryotes in the soil layer by the layer of the depth to $15 \mathrm{~cm}$. It was found that the effects of pyrogenic load remain evident for several years after the fires, manifesting in decrease of the height and projected area of herbage, the number and biomass of algae and cyanobacteria in the soil, especially to the depth of $5 \mathrm{~cm}$. Multivariate general linear models were used to test the significance of the dependence of quantitative characteristics of vegetation, microalgae, and cyanoprokaryotes on environmental predictors (season, year, soil layer, and fire). In the model, $75.2 \%$ of the grass height variability and $91.6 \%$ of the grass projected area variability could be explained by the predictors under consideration. In the series SP1 $\rightarrow \mathrm{SP} 2 \rightarrow \mathrm{SP} 3 \rightarrow \mathrm{SP} 4$ the grass height and projected area decreased. The differences in the projected area of the grass stand were most evident in spring. The model explained $89.1 \%$ of the variation in abundance and $91.6 \%$ of the variation in biomass of Bacillariophyceae. The abundance of Bacillariophyceae was greater in the upper soil layer than in the lower layer and decreased with depth. The abundance of this group of algae decreased in the series SP1 $\rightarrow$ SP2 $\rightarrow$ SP3 $\rightarrow$ SP4 at depths of 0-5 and $5-$ $10 \mathrm{~cm}$. Changes in abundances of Chlorophyta, Streptophyta, Heterokontophyta (Xanthophyceae and Eustigmatophyceae) equaling 47.6\% could also be explained by the model. The abundance of this group of algae was greatest in the upper soil layer. In the upper soil layer, the maximum abundance of Chlorophyta, Streptophyta, and Heterokontophyta (Xanthophyceae and Eustigmatophyceae) was recorded for Polygon SP1 and the minimum for Polygon SP3. Within the model, $48.0 \%$ of the variation in biomass of Chlorophyta, Streptophyta, and Heterokontophyta (Xanthophyceae and Eustigmatophyceae) was explained by the environmental predictors. The biomass trend was coherent with the population trend. A special feature was that there was a significant increase in biomass at 10-15 cm depth at Polygon SP3 compared to other polygons at this depth. The model was able to explain $61.8 \%$ of the variation in abundance and $66.7 \%$ of the variation in cyanobacteria biomass. The highest abundance of cyanobacteria was found in the upper soil layer of polygon SP1. Somewhat lower numbers of cyanobacteria were at polygons SP2 and SP4, and the lowest were found in the upper soil layer at polygon SP3. In turn, the highest number of cyanobacteria was found particularly at this polygon in the $5-10 \mathrm{~cm}$ layer. The biomass in the $0-5 \mathrm{~cm}$ layer was coherent with the abundance pattern of this group. The research results confirmed that the quantitative characteristics of the higher vegetation (height and projected area) as well as of microalgae and cyanobacteria (abundance and biomass) may be used in bioindication of the dynamics of postpyrogenic processes in steppe ecosystems.

Keywords: grass height and projected area; abundance and biomass of microalgae and cyanobacteria; bioindication.

\section{Introduction}

Ecosystems formed by herbaceous vegetation are widely distributed in different continents and in a broad range of climatic conditions (Butterbach-Bahl et al., 2011; Zerbo et al., 2016). They provide a wide spectrum of ecological services (Smelansky \& Tishkov, 2012; Lachashvili et al., 2017; Leßmeister et al., 2019). The study of their biodiversity, functioning regularities, resistance to various factors of natural and anthropogenic origin is currently considered among the priority scientific problems (Feng \& Squires, 2020; Siebert et al., 2020; Freitag et al., 2021). The steppe ecosystems of Europe have a special position in the entire diversity of herbaceous ecosystems. These are ecosystems dominated by perennial xerophytic plants, mainly sod grasses of the geera Stipa, Festuca, Agropyron, Koeleria, etc. The diversity of European steppe ecosystems is determined primarily by the heterogeneity of climatic conditions and increasing continentality in the direction from north-west to south-east. The northernmost variant, meadow steppes, is firstly replaced by a strip of true steppes and then by desert steppes (Butterbach-Bahl et al., 2011). For true steppes, the predominance of herbaceous perennial xerophytes (Stipa capillata L., S. ucrainica P. Smirn, S. lessingiana Trin. Et Rupr., Koeleria cristata (L.)
Pers, Festuca pseudovina Hack. ex Wiesb.) with inclusion of mesophytes and xeromesophytes is typical. Currently, the area of natural steppe vegetation is greatly modified by the human activity. A huge area of land is occupied by agriculture, industry, including mining, pipelines, transport routes, etc. As a result, only a small area of steppe natural vegetation has survived, mainly in protected areas. The Falz-Fein Biosphere Reserve Askania Nova is the largest steppe reserve in Europe $\left(330.3 \mathrm{~km}^{2}\right)$. Its history dates back to 1828 . The vegetation complexes of the reserve were under the reserve regime for a long time, which makes it possible for us to consider the steppe ecosystems of the Falz-Fein Biosphere Reserve Askania Nova as reference ones.

Despite the strict protection, the steppes of the reserve are periodically affected by fires. Fire in herbaceous ecosystems is a quite common phenomenon of both natural and anthropogenic origin. The processes of postpyrogenic restoration of such ecosystems are of considerable interest. This is important from the perspective of assessing possible losses of biodiversity (Reed-Dustin et al., 2016), reduction of ecosystem productivity (Bates et al., 2020), and soil fertility (Allen et al., 2011). Such studies are relevant due to the need for developing management strategies for steppe ecosystems after fires (Mata-González et al., 2018; Bates et al., 2019; Davies \& 
Dean, 2019; Nouwakpo et al., 2020). The significant fluctuations in the intensity of fires, frequency of their recurrence, seasonality with overlap with extreme climatic events (droughts), grazing, etc. considerably complicate the prediction of the post-pyrogenic effects and management of ecosystems during the recovery phase (Savadogo et al., 2017). The management significance of possible estimates and predictions may be improved by maximizing the extent of the studies on post-pyrogenic effects at the level of different groups of living organisms of steppe ecosystems (Kang et al., 2007; Gongalsky et al., 2012; Zaitsev et al., 2014; MuñozRojas et al., 2016; Tang et al., 2018).

Vegetation cover plays a special role in assessing the structure and functions of ecosystems. The projected area is a fairly simple and informative indicator of vegetation condition (Bonham \& Clark, 2005; Chen et al., 2009; Zhukov et al., 2019). The projected area is the value of the horizontal projection of aboveground plant organs. Other key ecosystem variables such as aboveground biomass, sawfly biomass, and leaf area index (LAI) may be reliably estimated using projected area (Chen et al., 2009). The projected area of soil vegetation is an important anti-erosion factor (Stred'anský et al., 2015). Developing a method to accurately determine projective vegetation cover to prevent soil erosion is important (Olmstead et al., 2004). The eye-catching determinations of projected area are context-dependent and subjective (Rasmussen, 2004), but are still widely used in practice (Jensen et al., 2004; Zhukov et al., 2018, 2019). The pointframe method was also developed (Krebs et al., 2003). This method is considered objective and is recommended as a standard protocol, but is very time-consuming, usually requiring $2-3$ hours for measurements within a single site (Chen et al., 2009).

Cyanobacteria (Cyanoprokaryota, Cyanophyta) are an extremely diverse group of prokaryotes. Their adaptive abilities, along with their potential to survive extreme conditions, make them cosmopolitans. They are found in virtually every habitat on Earth where life may exist. Cyanobacteria are extremely widespread: in seas, freshwater and hyperhaline water bodies, soils, snow and ice, hot springs, aerophytic conditions, etc. (Hoffman, 1999; Liu et al., 2016). Cyanobacteria are ranked first on the planet in resistance to extreme factors (Rampelotto, 2013). Cyanobacteria are characterized by a high ecological plasticity, so they occur in various, often even extreme habitats (Soares et al., 2013; Davydov, 2014; Pelechata et al., 2016), namely, in the marine environment (Hoffman, 1999; Engene et al., 2013; Arabadzhy-Tipenko, 2020), freshwater (McGregor et al., 2007; Okello et al., 2009; Okhapkin, 2015), soils (Davydov \& Patova, 2018; Shekhovtseva \& Mal'tseva, 2015; Maltseva et al., 2017; Maltsev \& Maltseva, 2018), the biological soil crust, snow, cryoconites, etc. (Gaysina et al., 2019). The stress to which algae may be subjected is divided into two types: limiting stress caused by insufficient supplies of resources (such as insufficient light or nutrient deficiencies), and destructive stress (as a result of damage caused by adverse conditions) (Davison $\&$ Pearson, 1996). Some Cyanobacteria can live in soil and other terrestrial habitats, where they are important in the functional processes of ecosystems and nutrient circulation (Whitton \& Potts, 2006; Chaurasia, 2015). Other species colonize surfaces by attaching to rocks or sediments, sometimes forming microbial mats (Golubic \& Seong-Joo, 1999; Stal, 2012). The cyanobacteria have an impressive ability to colonize such barren substrates as volcanic ash, desert sand, and rocks (Dor \& Danin, 1996). Another excellent feature of cyanobacteria is their ability to survive extremely high and low temperatures. Cyanobacteria are inhabitants of hot springs (Castenholz, 1977; Ward \& Castenholz, 2006), mountain streams (Dufford et al., 1987), Arctic and Antarctic lakes (Zakhia et al., 2008), snow and ice (Laamanen, 1996). The cyanobacteria also form symbiotic associations with animals and plants (Amar Nath Rai, 2018). Cyanobacteria species show different optima with respect to environmental parameters such as temperature, light or nutrient content. Cyanobacteria are very well adapted to nutrient-poor conditions and limited light availability (Reynolds, 1984).

Heterokontophyta, Chlorophyta, Streptophyta comprise a numerous group of eukaryotic algae found in both aquatic (freshwater and marine) and terrestrial ecosystems. From the ecological point of view, this is a rather heterogeneous group of algae that includes both stenotopic and eurytopic species. They play an important role in the functional processes of ecosystems, are of great practical importance and much attention is currently paid to the study of their diversity (Mamaeva et al., 2018; Liu et al., 2019; Kezlya et al., 2020; Kulikovskiy et al., 2020a, 2020b, 2020c; Maltsev et al., 2021a, 2021b).

In the study, we tested the following hypothesis: the higher plants, microalgae and cyanobacteria may be used in bioindication of recovery dynamics of the steppe ecosystems after fires. The objective of the study was analysis of the impact of fires in steppe ecosystems on the projected area and height of grasses, abundance and biomass of soil microalgae and Cyanobacteria.

\section{Matherial and methods}

The Falz-Fein Biosphere Reserve Askania Nova is located in the south of Ukraine in the zone of fescue-feather grass steppes. The measurements of the total projective cover and the height of the grass stand, abundance and biomass of soil microalgae and cyanobacteria were conducted seasonally (April, July, October) during 2010-2011 on four stationary polygons (SP) located in steppe ecosystems, where the protection regime had been in operation since 1898 (SP1-SP3) and since 1966 (SP4). SP1 ( $500 \mathrm{~m}^{2}$ area, block 42) had not been exposed to fire during the twenty years preceding our study and was chosen as the control. SP2 (300 $\mathrm{m}^{2}$ area, block 59), was exposed to fire in 2001 . On SP3 $\left(250 \mathrm{~m}^{2}\right.$ area, block 42), there was a fire in 2005. On SP4 (500 $\mathrm{m}^{2}$ area, Pivnichna plot) there were fires in 2001 and 2004. The projective cover of grasses, taking into account all layers, was determined using a square grid of $1 \mathrm{~m}^{2}$ divided by twine into separate cells of $10 \mathrm{~cm}^{2}$. On each polygon, to determine the projective cover, we laid five $1 \mathrm{~m}^{2}$ recording plots located in the corners of the polygon and one in the centre. Projective cover of grasses was expressed as percentage. The height of each layer was measured with a tape measure in each survey plot with the accuracy of $1 \mathrm{~cm}$. Soil samples were examined for algae and cyanobacteria. Each sample was formed from 5 10 individual specimens with an area of $25 \mathrm{~cm}^{2}$ collected randomly within the corresponding polygon. A total of 72 soil samples were collected to determine the abundance and biomass of algae and cyanobacteria. Algae were detected using an optical microscope XSP-128B at the magnification $\times 1000$, and using oil immersion. The literature used for identification included Ettl \& Gärtner (1995, 2014), and others (Ettl, 1978, 1983; Krammer \& Lange-Bertalot, 1986, 1988; Ettl \& Gartner, 1988b, 1988a; Komárek \& Anagnostidis, 2005; Komárek, 2013). The referential system of Cyanobacteria was used in accordance to the reports (Komárek \& Anagnostidis, 2005; Komárek, 2013), the rest of the groups - according to 'Syllabus of Plant Families' (Frey, 2015). Cell numbers of algae and cyanobacteria were determined by direct counting (Kalinichenko et al., 2018; Fomina, 2020). This method makes it possible not only to determine the total number of cells, but also to classify them according to morphological features into three groups: Cyanobacteria (first group), Bacillariophyceae (second group) and together Chlorophyta, Streptophyta, Xanthophyceae and Eustigmatophyceae from Heterokontophyta (third group). Biomass was determined by the volume-calculation method based on the number of cells and their size characteristics. The data were recalculated per 1 gram of absolutely dry soil. All measurements were performed in three repetitions.

Multivariate General Linear Models were used to test the significance of the dependence of quantitative characteristics of vegetation on environmental predictors (Software package Statistica). Two multivariate GLMs were performed. The first multivariate GLM was performed for plant cover height and projective cover. The variables season (three levels), year (two levels), polygon (four levels) and season $\times$ year, season $\times$ polygon, year $\times$ polygon (interaction between predictors) are treated as categorical predictors. The second multivariate GLM was performed for algae and Cyanobacteria abundance and biomass with the year (two levels), polygon (four levels), soil layer (three levels) and layer $\times$ year, layer $\times$ polygon, layer $\times$ polygon (interaction between predictors) as categorical predictors. The Planned Comparisons approach was used to test the differences between individual treatments.

\section{Results}

The predictors considered were statistically significant for explaining the height and projective cover of grass stands (Table 1). Within the mo- 
del, $75.2 \%$ of grass height variability can be explained by the considered predictors $\left(\mathrm{R}_{\mathrm{adj}}{ }^{2}=0.75, \mathrm{~F}=22.3, \mathrm{P}<0.001\right)$. The grass height increased in the same manner throughout the growing season (Fig. 1). In 2010, the rate of grass height increase during the season was higher than in 2011. In the order of polygons $\mathrm{SP} 1 \rightarrow \mathrm{SP} 2 \rightarrow \mathrm{SP} 3 \rightarrow \mathrm{SP} 4$, the grass stand height decreased. The variation in grass height was most apparent in spring. A total of $91.6 \%$ of the variability of grass projective cover can be explained by the predictors considered $\left(\mathrm{R}_{\mathrm{adj}}{ }^{2}=0.92, \mathrm{~F}=77.7, \mathrm{P}<0.001\right)$. The projective cover reached its maximum in summer. The projective cover was higher in 2011 than in 2010. In the order of polygons SP1 $\rightarrow$ SP2 $\rightarrow$ SP3 $\rightarrow \mathrm{SP} 4$, the projective cover of grasses decreased. The differences in projective cover of the grass stand were most pronounced in spring.

Table 1

Multivariate GLM results examining the effect of polygon type, season and year as predictor on plant coverage height and plant projective cover

\begin{tabular}{lcrccc}
\hline \multicolumn{1}{c}{ Effect } & $\begin{array}{c}\text { Wilks } \\
\text { test value }\end{array}$ & $F$-ratio & $\begin{array}{c}\text { Effect degree } \\
\text { of freedom }\end{array}$ & $\begin{array}{c}\text { Error degree } \\
\text { of freedom }\end{array}$ & $P$-level \\
\hline Intercept & 0.001 & 45726.70 & 2 & 101 & $<0.001$ \\
Polygon* & 0.077 & 87.30 & 6 & 202 & $<0.001$ \\
Year** & 0.672 & 24.67 & 2 & 101 & $<0.001$ \\
Season*** & 0.324 & 38.51 & 4 & 202 & $<0.001$ \\
Polygon $\times$ Year & 0.665 & 7.80 & 6 & 202 & $<0.001$ \\
Season $\times$ Polygon & 0.254 & 17.14 & 12 & 202 & $<0.001$ \\
Year $\times$ Season & 0.712 & 9.36 & 4 & 202 & $<0.001$ \\
Error & 0.001 & 45726.70 & 2 & 101 & $<0.001$ \\
\hline
\end{tabular}

Note: * - polygon type (SP1-SP4); ** - year (2011 and 2012); *** - season (spring, summer, autumn).
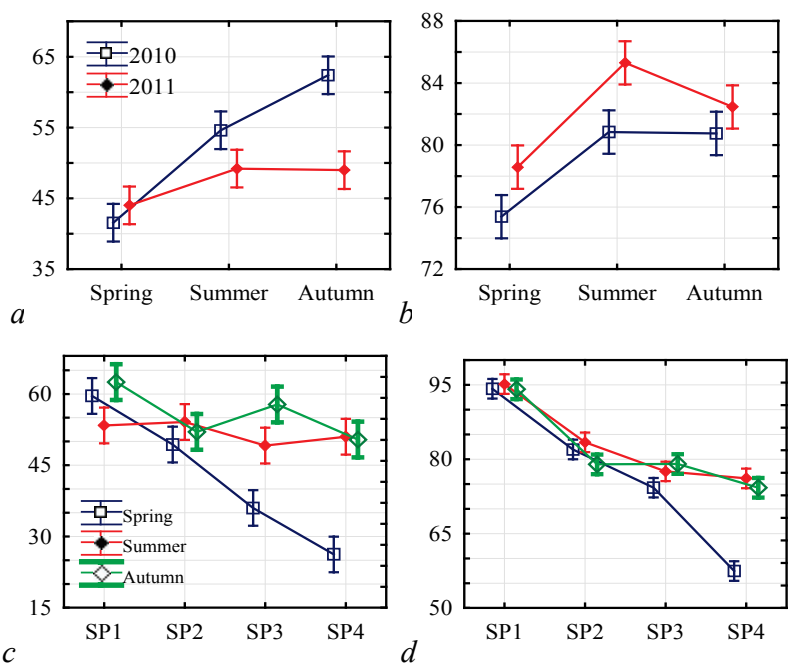

Fig. 1. The dependence of the plant cover height $(\mathrm{cm}, a, c)$ and plant projective cover $(\%, b, d)$ from the season $(c, d)$, year $(a, b)$ and burn effect $(c, d)$ : the vertical line indicates the standard deviation (SD)

The variables considered were statistically significant predictors of the abundance and biomass of algae and cyanobacteria (Table 2). Within the model, $89.1 \%$ of the variation in Bacillariophyceae abundance was explained $\left(\mathrm{R}_{\mathrm{adj}}{ }^{2}=0.89, \mathrm{~F}=286.2, \mathrm{P}<0.001\right)$. The abundance of Bacillariophyceae was greater in the upper soil layer than in the lower ones and decreased with depth (Fig. 2). The abundance of this group of algae decreased in the series SP1 $\rightarrow \mathrm{SP} 2 \rightarrow \mathrm{SP} 3 \rightarrow \mathrm{SP} 4$ at the depths of $0-5$ and $5-10 \mathrm{~cm}$. At the depth of $10-15 \mathrm{~cm}$ the differences in Bacillariophyceae abundance were not statistically significantly different. Within the model, $91.6 \%$ of the variation in Bacillariophyceae biomass was explained by the considered predictors $\left(\mathrm{R}_{\mathrm{adj}}{ }^{2}=0.92, \mathrm{~F}=379.7, \mathrm{P}<0.001\right)$. The highest biomass of Bacillariophyceae was in the upper soil layer. The biomass of this group of algae was the highest in the SP 1 polygon at the depth of 0 $5 \mathrm{~cm}$. Differences in Bacillariophyceae biomass in other polygons were statistically not significant at the same soil depths.

The $47.6 \%$ variation in abundance of Chlorophyta, Streptophyta, Heterokontophyta (Xanthophyceae and Eustigmatophyceae) can be explained in the model $\left(\mathrm{R}_{\mathrm{adj}}{ }^{2}=0.48, \mathrm{~F}=32.7, \mathrm{P}<0.001\right)$. The abundance of this group of algae was greatest in the upper soil layer. In the upper soil layer, the maximum abundance of Chlorophyta, Streptophyta, Heterokontophyta (Xanthophyceae and Eustigmatophyceae) was recorded for polygon $\mathrm{SP} 1$, and the minimum was recorded for polygon SP3. At greater depths, differences in the abundance of this group of algae were not statistically significantly different within the same soil layer. Within the model, $48.0 \%$ of the variation in the biomass of Chlorophyta, Streptophyta, Heterokontophyta (Xanthophyceae and Eustigmatophyceae) can be explained by the predictors considered $\left(\mathrm{R}_{\mathrm{adj}}{ }^{2}=0.48, \mathrm{~F}=33.2, \mathrm{P}<0.001\right)$. The dynamics of biomass was coherent with the dynamics of abundance. The peculiarity was that at the depth of $10-15 \mathrm{~cm}$ in polygon SP3 there was a significant increase in biomass compared to other polygons at this depth.

\section{Table 2}

Multivariate GLM results examining the effect of layer, polygon type, season and year as predictor on algae and cyanobacteria

\begin{tabular}{lccccc}
\hline \multicolumn{1}{c}{ Effect } & $\begin{array}{c}\text { Wilks } \\
\text { test value }\end{array}$ & $F$-ratio & $\begin{array}{c}\text { Effect degree } \\
\text { of freedom }\end{array}$ & $\begin{array}{c}\text { Error degree } \\
\text { of freedom }\end{array}$ & $P$-level \\
\hline Intercept & 0.09 & 1661.0 & 6 & 1043 & $<0.001$ \\
Layer* & 0.09 & 394.0 & 12 & 2086 & $<0.001$ \\
Season** & 0.71 & 33.2 & 12 & 2086 & $<0.001$ \\
Year*** & 0.79 & 46.7 & 6 & 1043 & $<0.001$ \\
Polygon**** & 0.41 & 59.9 & 18 & 2951 & $<0.001$ \\
Layer×Season & 0.63 & 21.7 & 24 & 3640 & $<0.001$ \\
Layer×Year & 0.65 & 41.8 & 12 & 2086 & $<0.001$ \\
Season×Year & 0.69 & 35.3 & 12 & 2086 & $<0.001$ \\
Layer×Polygon & 0.23 & 50.8 & 36 & 4583 & - \\
Season×Polygon & 0.58 & 16.7 & 36 & 4583 & - \\
Year×Polygon & 0.71 & 20.9 & 18 & 2951 & - \\
\hline
\end{tabular}

Note: * - layer (0-5, 5-10, 10-15 cm); ** - season (spring, summer, autumn); *** year (2011 and 2012); **** - polygon type (SP1-SP4).
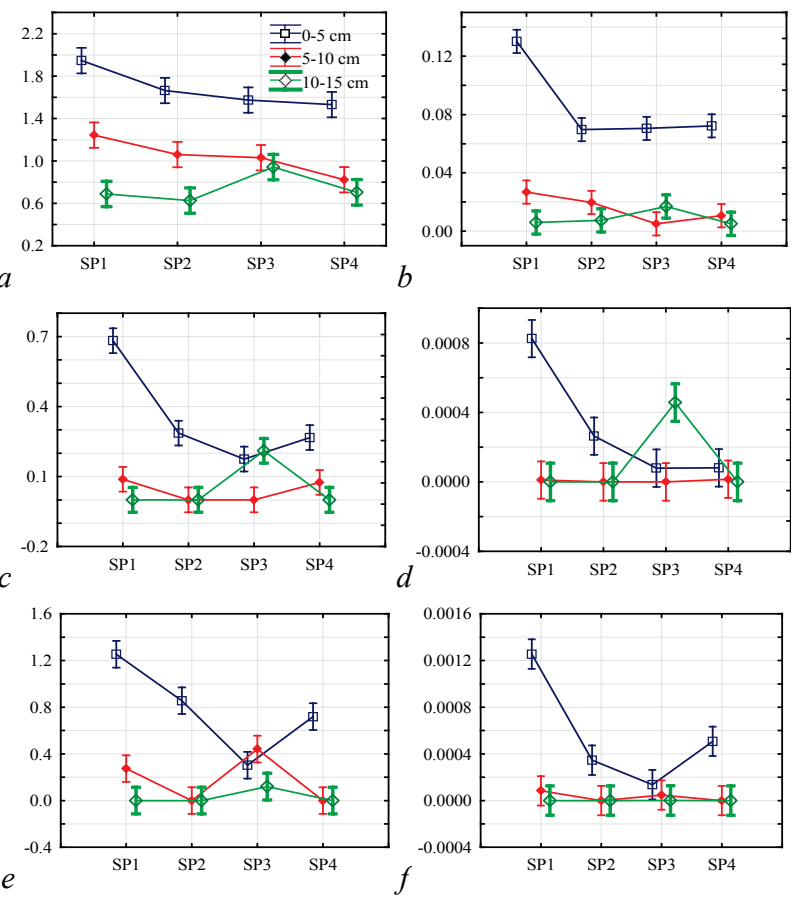

Fig. 2. Dynamics of abundance (logarithmic data: $a-$ Heterokontophyta (Bacillariophyceae), $c-$ Chlorophyta, Streptophyta, Heterokontophyta (Xanthophyceae and Eustigmatophyceae), $e-$ Cyanobacteria) and biomass (logarithmic data: $b$-Heterokontophyta (Bacillariophyceae), $d$-Chlorophyta, Streptophyta, Heterokontophyta (Xanthophyceae and Eustigmatophyceae), $f$-Cyanobacteria) as a function of soil layer and pyrogenic impact based on the results of the General Linear Model (taking into account the impact of season, year, and their interaction); the vertical line indicates the standard deviation (SD)

The model was able to explain $61.8 \%$ of the variation in abundance and $66.7 \%$ of the variation in biomass of Cyanobacteria $\left(\mathrm{R}_{\mathrm{adj}}{ }^{2}=0.62, \mathrm{~F}=\right.$ $57.2, \mathrm{P}<0.001$ and $\left.\mathrm{R}_{\mathrm{adj}}{ }^{2}=0.67, \mathrm{~F}=70.6, \mathrm{P}<0.001\right)$. The highest abundance of Cyanobacteria was found in the upper soil layer in polygon SP1. Somewhat lower abundance of Cyanobacteria was in polygons SP2 and 
SP4, and the lowest abundance was found in the upper soil layer in polygon SP3. In turn, it was this polygon, in the 5-10 cm layer, where we saw the highest Cyanobacteria abundance. Differences in Cyanobacteria biomass in layers 5-10 and 10-15 cm were not statistically significantly different in either layers and polygons. The biomass in $0-5 \mathrm{~cm}$ layer was coherent with the pattern found for the abundance of this group.

\section{Discussion}

Fires in herbaceous ecosystems can be both spontaneous, due to natural or anthropogenic factors, and purposeful, as a regulatory mechanism of the management system (Allen et al., 2011; Seger et al., 2014; Bates et al., 2020; Nouwakpo et al., 2020). Regardless of its origin, the pyrogenic load causes changes in ecosystems and, first of all, in the composition and structure of the phytosystems. As the studies showed, the pyrogenic impact on the steppe ecosystems continues to manifest itself during the next few years in the reduction of the projected area and height of the grass stand. This pattern was also recorded earlier (Zedler, 2007; Stavi, 2019). The consequence of this is a more pronounced contrast of temperature regime and humidity in the post-pyrogenic areas, to which only typically steppe species can successfully adapt. The mesophilic component in the narrowed ectopic conditions became less important. This is quite consistent with the conclusions that fire changes the course of natural transformation of the herbaceous ecosystem, associated with the intensification of the role of the mesophytic constituent and lignozoic component (Korotchenko \& Peregrym, 2012). For European steppes, in the absence of large ungulates, a tendency towards overgrowth with shrubs and, in some cases, with forest trees has been observed (Caragana frutex (L.) K. Koch., Rhamnus cathartica L., Acer tataricum L., Prumus stepposa Kotov, Ulmus minor Mill., Fraxinus excelsior L.) (Wesche et al., 2016). Fires can act as a barrier to the mesophytization of the steppe and allow the steppe stages to persist for a longer time. The positive effect of regulated burning on the restoration of steppe vegetation has been also noted in the invasion of arboreal vegetation into sagebrush steppe communities in North America (Davies \& Dean, 2019; Davies et al., 2019; Nouwakpo et al., 2020). Our results indicate that the greatest differences in height and projective vegetation cover were observed in spring and subsequently during the growing season these differences evened out. The spring period is the most favourable for the development of mesophilic fraction of flora. In spring, the most favourable living conditions are formed for plant species that are demanding in terms of water content in soil and are not adapted to live in extreme thermal regimes. Obviously, such species are most affected by fires. The restoration rate of the mesophilic fraction is significantly delayed compared to the restoration rate of the xerophilic fraction of the flora.

The effects of fires in the steppe are not the only changes in the characteristics of the vegetation, but also the transformation of soil microbial communities (Shcherbyna et al., 2017). The fires significantly change the properties of the soil as a living environment and affect the soil vegetation cover. The grass vegetation significantly affects the light and water regime of the soil. In the absence of vegetation cover and dead plant litter, we should expect a significant overcooling of the upper soil layers in winter, and in summer the soil would be subjected to a significant overheating. The vegetation cover also protects the soil from water and wind erosion and reduces moisture evaporation. A number of Cyanobacteria species are adapted to live at extremely high or low temperatures (Mutalipassi et al., 2019). A low temperature by itself does not necessarily damage the organism, but the formation of ice crystals can be fatal to it due to mechanical damage or changes in the concentrations of osmotically active solvents (Fogg et al., 1973; Fogg, 1999). The stress may occur during sudden changes in temperature (Holmstrup et al., 1999; Sinetova \& Los, 2016). The microclimate temperature in the immediate proximity of the algae can differ significantly from the temperature in the broader environment. Therefore, it is necessary to distinguish between cooling and freezing. At high temperatures, the proximal cause of stress may be oxygen deficiency, oxygen being much less soluble in warm water than in cold water (Brook, 1980; Hemlata \& Fatma, 2009).

In arid ecosystems, the soil surface is covered with biological soil crusts (BSC), which are composed of algae and cyanobacteria (Bowker et al., 2004; Aguilar et al., 2009; Mager \& Thomas, 2011; DettweilerRobinson et al., 2013; Warren et al., 2020). Their importance is associated with both a wide range of ecosystem services and the perspective of using valuable algae and cyanobacteria as a natural resource for practical use (Maltsev et al., 2020), mass production of biomass, preparation of inoculum, and soil inoculation (Liu et al., 2010; Lababpour, 2016; Antoninka et al., 2018), monitoring and control of primary successions in various man-made ecotopes and sandy habitats (Maestre et al., 2002; Myers \& Davis, 2003; Barger et al., 2006; Crittenden et al., 2007) and secondary successions, including after pyrogenic destruction of various ecosystems (Allen et al., 2011; Warren et al., 2015, 2020; Aanderud et al., 2019). The biological soil crusts (bio-crusts) are the upper soil communities consisting of many groups of organisms: bacteria, cyanobacteria, microalgae, microfungi, mosses, lichens, protozoa and invertebrates (Belnap \& Eldridge, 2001). Closely related to soil particles, these groups provide vital ecological functions in soil ecosystems. They contribute to nutrient cycling, increase the soil stability, reduce evaporation, and increase the soil moisture (Chamizo et al., 2016). Globally, biocrusts contribute $40 \%$ to $85 \%$ of biological nitrogen fixation by terrestrial organisms and $15 \%$ of global net terrestrial primary production (Rodriguez-Caballero et al., 2018). Biocrusts are often pioneer communities in ecosystems that are degraded as a result of natural or anthropogenic activities, for example, habitats affected by fires or that emerged after glacial retreat, mining areas, etc. Biocrusts induce the formation of soil and promote the restoration of natural vegetation (Baumann et al., 2018; Samolov et al., 2020; Tucker et al., 2020). The trophic structure of the biocrust determines the quantity and quality of nutrients entering the soil. The primary producers, mostly cyanobacteria, fix atmospheric carbon and nitrogen, which then become available to other soil biota. The soil under the crust can contain more than $300 \%$ more carbon and $200 \%$ more nitrogen than soil without the biocrust (Johnson et al., 2007; Pointing \& Belnap, 2012). The nutrient enrichment of sub-crust soils promotes the localized growth of heterotrophic organisms, including bacteria, fungi, and nematodes (McLendon \& Redente, 1992; Darby et al., 2007; Crenshaw et al., 2008). The ecosystemic role of BSC is related first of all to the formation of primary organic matter rich in nitrogen due to nitrogen-fixing cyanobacteria, provoking activity of heterotrophic microflora, soil animals, improvement of physical and chemical properties of soils (Zhang et al., 2006; Aznar et al., 2016). BSC is understood to have an effect on the germination ability of seeds of many vascular plant species (Rivera-Aguilar et al., 2005; Escudero et al., 2007; Langhans et al., 2009). Inhibitory effects of BSC on vascular plant species, especially from arid ecosystems, were reported (Prasse \& Bornkamm, 2000; Hawkes, 2004). Therefore, many researchers emphasize the importance of detailed and long-term studies of BSCs and their functional role in biotic and abiotically changing environments (Aguilar et al., 2009; Mager \& Thomas, 2011).

The development of algal populations is regulated not only by physical and chemical factors (Richardson et al., 1998), but also biological factors, such as predation (Maar et al., 2002; Elloumi et al., 2008) and competition between species (Mallin \& Paerl, 1994; Pinckney et al., 1998). However, the availability of nutrients remains the main factor controlling the composition and biomass of algal communities (Ortega-Mayagoitia et al., 2003; López-Flores et al., 2006). These abiotic parameters vary in time and directly or indirectly influence the composition and abundance of algae flora (Koffi, 2009). As reported earlier, the species composition of algae and cyanobacteria of Askania Nova steppe ecosystems changes after fires (Shcherbyna et al., 2017). The pyrogenic load leads to a decrease in the abundance and biomass of algae and cyanobacteria in the soil of steppe ecosystems. The most significant changes were observed to the depth of $5 \mathrm{~cm}$ and persisted for several years after the fire. This indicated a rather slow process of recovery of quantitative indicators of algae and cyanobacteria communities in BSC after pyrogenic load. Bacillariophyceae were the most abundant (and biomass) both in the control plot and the post-pyrogenic plots, with cyanobacteria in the second place. According to other studies, cyanobacteria in steppe and other arid ecosystems can exceed other groups of microalgae by abundance (Bu et al., 2014; Antoninka et al., 2018). At the same time, there are reports that cyanobacteria may be more susceptible to fire than other BSC components (Bowker et al., 2004). The results show that algae and cyanobacteria are very sensitive to post-pyrogenic loads. A decrease in quantitative indicators was 
observed, which is also directly related to the change in the volume of their ecosystem functions. The extent to which this affects the processes of humus accumulation observed under pyrogenic load, the functioning of other soil microorganisms, and the biological activity of soils in general cannot be unequivocally assessed at this stage of research. This may be the subject of further research and be of great importance both for detailing the processes of post-pyrogenic transformation of herbaceous ecosystems, and for evaluating the totality of consequences when using fires to regulate the development of herbaceous ecosystems.

\section{Conclusion}

In steppe ecosystems the height and projected area of higher vegetation, the abundance and biomass of soil microalgae and cyanobacteria change significantly after fires. The consequences of pyrogenic load remain noticeable for several years, seen in decrease of height and projected area of herbage, abundance and biomass of algae and cyanobacteria in the soil, especially to the depth of $5 \mathrm{~cm}$. The statistically significant dependencies obtained between the studied characteristics and environmental predictors (season, year, soil layer, fire) within the framework of multidimensional general linear models confirm that quantitative characteristics of higher vegetation (height and projected area), microalgae and cyanobacteria (abundance and biomass), may be used in bioindication of the dynamics of postpyrogenic processes in steppe ecosystems.

\section{References}

Aanderud, Z. T., Bahr, J., Robinson, D. M., Belnap, J., Campbell, T. P., Gill, R. A., McMillian, B., \& St. Clair, S. (2019). The burning of biocrusts facilitates the emergence of a bare soil community of poorly-connected chemoheterotrophic bacteria with depressed ecosystem services. Frontiers in Ecology and Evolution, 467, 1-14.

Allen, E. B., Steers, R. J., \& Dickens, S. J. (2011). Impacts of fire and invasive species on desert soil ecology. Rangeland Ecology and Management, 64(5), 450-462.

Antoninka, A., Bowker, M. A., Chuckran, P., Barger, N. N., Reed, S., \& Belnap, J. (2018). Maximizing establishment and survivorship of field-collected and greenhouse-cultivated biocrusts in a semi-cold desert. Plant and Soil, 429, 213-225.

Arabadzhy-Tipenko, L. I. (2020). Ecological and floristic characteristics of Cyanophyceae of Pryazovskyi National Nature Park. Agrology, 3(2), 66-79.

Aznar, J. M., González-Pérez, J. A., Badía, D., \& Martí, C. (2016). At what depth are the properties of a gypseous forest topsoil affected by burning? Land Degradation and Development, 27(5), 1344-1353.

Barger, N. N., Herrick, J. E., Van Zee, J., \& Belnap, J. (2006). Impacts of biological soil crust disturbance and composition on $\mathrm{C}$ and $\mathrm{N}$ loss from water erosion. Biogeochemistry, 77(2), 247-263.

Bates, J. D., Boyd, C. S., \& Davies, K. W. (2020). Longer-term post-fire succession on Wyoming big sagebrush steppe. International Journal of Wildland Fire, 29(3), 229

Bates, J. D., Davies, K. W., Bournoville, J., Boyd, C., O’Connor, R., \& Svejcar, T. J. (2019). Herbaceous biomass response to prescribed fire in juniper-encroached sagebrush steppe. Rangeland Ecology and Management, 72(1), 28-35.

Baumann, K., Jung, P., Samolov, E., Lehnert, L. W., Büdel, B., Karsten, U., Bendix, J., Achilles, S., Schermer, M., Matus, F., Oses, R., Osses, P., Morshedizad, M. Oehlschläger, C., Hu, Y., Klysubun, W., \& Leinweber, P. (2018). Biological soil crusts along a climatic gradient in Chile: Richness and imprints of phototrophic microorganisms in phosphorus biogeochemical cycling. Soil Biology and Biochemistry, 127, 286-300.

Belnap, J., \& Eldridge, D. (2001). Disturbance and recovery of biological soil crusts. In: Belnap, J., \& Lange, O. L. (Eds.). Biological soil crusts: Structure, function, and management. Springer, Berlin, Heidelberg. Pp. 363-383.

Bonham, C. D., \& Clark, D. L. (2005). Quantification of plant cover estimates. Grassland Science, 51(2), 129-137.

Bowker, M. A., Belnap, J., Rosentreter, R., \& Graham, B. (2004). Wildfire-resistant biological soil crusts and fire-induced loss of soil stability in Palouse prairies, USA. Applied Soil Ecology, 26(1), 41-52.

Brook, A. J. (1980). Thermophilic microorganisms and life at high temperatures. Geoderma, 24(4), 363-364.

Bu, C., Wu, S., Yang, Y., \& Zheng, M. (2014). Identification of factors influencing the restoration of Cyanobacteria-dominated biological soil crusts. PLoS One, 9(3), e90049.

Butterbach-Bahl, K., Kögel-Knabner, I., \& Han, X. (2011). Steppe ecosystems and climate and land-use changes - vulnerability, feedbacks and possibilities for adaptation. Plant and Soil, 340, 1-6.

Castenholz, R. W. (1977). The effect of sulfide on the blue-green algae of hot springs II. Yellowstone National Park. Microbial Ecology, 3(2), 79-105.
Chamizo, S., Cantón, Y., Rodríguez-Caballero, E., \& Domingo, F. (2016). Biocrusts positively affect the soil water balance in semiarid ecosystems. Ecohydrology, 9(7), 1208-1221.

Chaurasia, A. (2015). Cyanobacterial biodiversity and associated ecosystem services: Introduction to the special issue. Biodiversity and Conservation, 24(4), 707-710.

Chen, W., Li, J., Zhang, Y., Zhou, F., Koehler, K., LeBlanc, S., Fraser, R., Olthof, I., Zhang, Y., \& Wang, J. (2009). Relating biomass and leaf area index to nondestructive measurements in order to monitor changes in arctic vegetation. Arctic, 62(3), 257-369.

Crenshaw, C. L., Lauber, C., Sinsabaugh, R. L., \& Stavely, L. K. (2008). Fungal control of nitrous oxide production in semiarid grassland. Biogeochemistry, 87(1), 17-27.

Crittenden, P. D., Llimona, X., \& Sancho, L. G. (2007). Lichenized unicellular cyanobacteria fix nitrogen in the light. Canadian Journal of Botany, 85(10), 1003-1006.

Darby, B. J., Neher, D. A., \& Belnap, J. (2007). Soil nematode communities are ecologically more mature beneath late- than early-successional stage biological soil crusts. Applied Soil Ecology, 35(1), 203-212.

Davies, K. W., \& Dean, A. E. (2019). Prescribed summer fire and seeding applied to restore Juniper-encroached and exotic annual grass-invaded sagebrush steppe. Rangeland Ecology and Management, 72(4), 635-639.

Davies, K. W., Rios, R. C., Bates, J. D., Johnson, D. D., Kerby, J., \& Boyd, C. S. (2019). To burn or not to burn: Comparing reintroducing fire with cutting an encroaching conifer for conservation of an imperiled shrub-steppe. Ecology and Evolution, 9(16), 9137-9148.

Davison, I. R., \& Pearson, G. A. (1996). Stress tolerance in intertidal seaweeds. Journal of Phycology, 32(2), 197-211.

Davydov, D. (2014). Diversity of the Cyanoprokaryota of the area of settlement Pyramiden, West Spitsbergen Island, Spitsbergen Archipelago. Folia Cryptogamica Estonica, 51, 13.

Davydov, D., \& Patova, E. (2018). The diversity of Cyanoprokaryota from freshwater and terrestrial habitats in the Eurasian Arctic and Hypoarctic. Hydrobiologia, 811(1), 119-137.

Dettweiler-Robinson, E., Bakker, J. D., \& Grace, J. B. (2013). Controls of biological soil crust cover and composition shift with succession in sagebrush shrubsteppe. Journal of Arid Environments, 94, 96-104.

Dor, I., \& Danin, A. (1996). Cyanobacterial desert crusts in the Dead Sea Valley, Israel map: 1. Algological Studies/Archiv Für Hydrobiologie, Supplement Volumes, 83, 197-206.

Dufford, R. G., Zimmermann, H. J., Cline, L. D., \& Ward, J. V. (1987). Responses of epilithic algae to regulation of rocky mountain streams. In: Craig, J. F., \& Kemper, J. B. (Eds.). Regulated Streams. Springer US, Boston. Pp. 383-390.

Elloumi, J., Guermazi, W., Ayadi, H., Bouaïn, A., \& Aleya, L. (2008). Detection of water and sediments pollution of an arid saltern (Sfax, Tunisia) by coupling the distribution of microorganisms with hydrocarbons. Water, Air, and Soil Pollution, 187, 157-171.

Engene, N., Paul, V. J., Byrum, T., Gerwick, W. H., Thor, A., \& Ellisman, M. H. (2013). Five chemically rich species of tropical marine cyanobacteria of the genus Okeania gen. nov. (Oscillatoriales, Cyanoprokaryota). Journal of Phycology, 49(6), 1095-1106.

Escudero, A., Martínez, I., de la Cruz, A., Otálora, M. A. G., \& Maestre, F. T. (2007). Soil lichens have species-specific effects on the seedling emergence of three gypsophile plant species. Journal of Arid Environments, 70(1), 18-28.

Ettl, H. (1978). Xanthophyceae, 1. Teil. In: Ettl, H., Gerloff, J., \& Heynig, H. (Eds.). Süßwasserflora von Mitteleuropa. Band 3(14). VEB Gustav Fischer-Verlag, Stuttgart, New York.

Ettl, H. (1983). Chlorophyta I (Phytomonadina). In: Ettl, H., Gerloff, J., Heynig, H., \& Mollenhauer, D. (Eds.). Süßwasserflora von Mitteleuropa. Band 9. Gustav Fischer Verlag, Stuttgart, New York.

Ettl, H., \& Gartner, G. (1988a). Chlorophyta II, Tetrasporales, Chlorococcales, Gloeodendrales. In: Ettl, H., Gerloff, J., \& Heynig, H. (Eds.). Süßwasserflora von Mitteleuropa. Gustav Fischer Verlag, Stuttgart.

Ettl, H., \& Gartner, G. (1988b). Tetrasporales, Chlorococcales, Gloeodendrales, Chlorophyta II. In: Ettl, H., Gerloff, J., \& Heynig, H. (Eds.). Süswasserflora von Mitteleuropa. Gustav Fischer Verlag, Stuttgart.

Ettl, H., \& Gärtner, G. (1995). Syllabus der Boden-, Luft- und Flechtenalgen. Gustav Fischer, Stuttgart

Ettl, H., \& Gartner, G. (2014). Syllabus der Boden-, Luft und Flechtenalgen. 2 Aufl. Springer Spektrum, Berlin, Heidelberg.

Feng, H., \& Squires, V. R. (2020). Socio-environmental dynamics of alpine grasslands, steppes and meadows of the Qinghai-Tibetan Plateau, China: A commentary. Applied Sciences, 10(18), 6488.

Fogg, G. E. (1999). The biology of polar habitats. Cambridge The University Press, Cambridge.

Fogg, G. E., Stewart, W. D. P., Fay, P., \& Walsby, A. E. (1973). The blue-green algae. Academic Press, London, New York. 
Fomina, N. V. (2020). Algomonitoring of chernozem leached in agrocenoses of the forest-steppe of the Krasnoyarsk Territory. IOP Conference Series: Materials Science and Engineering, 919, 062046.

Freitag, M., Kamp, J., Dara, A., Kuemmerle, T., Sidorova, T. V., Stimemann, I. A. Velbert, F., \& Hölzel, N. (2021). Post-soviet shifts in grazing and fire regimes changed the functional plant community composition on the Eurasian steppe. Global Change Biology, 27(2), $388-401$

Frey, W. (2015). Syllabus of plant families. Adolf Engler's Syllabus der Pflanzenfamilien. Part 2/1: Photoautotrophic eukaryotic Algae. Schweizerbart Science Publishers, Stuttgart.

Gaysina, L. A., Saraf, A., \& Singh, P. (2019). Cyanobacteria in diverse habitats. In: Mishra, A. K., \& Tiwari, D. N. (Eds.). Cyanobacteria. Elsevier, New York Pp. 1-28.

Golubic, S., \& Seong-Joo, L. (1999). Early cyanobacterial fossil record: Preservation, palaeoenvironments and identification. European Journal of Phycology, 34(4), 339-348.

Gongalsky, K. B., Malmström, A., Zaitsev, A. S., Shakhab, S. V., Bengtsson, J., \& Persson, T. (2012). Do burned areas recover from inside? An experiment with soil fauna in a heterogeneous landscape. Applied Soil Ecology, 59, 73-86.

Hawkes, C. V. (2004). Effects of biological soil crusts on seed germination of four endangered herbs in a xeric Florida shrubland during drought. Plant Ecology, $170(1), 121-134$

Hemlata, \& Fatma, T. (2009). Screening of cyanobacteria for phycobiliproteins and effect of different environmental stress on its yield. Bulletin of Environmental Contamination and Toxicology, 83(4), 509-515.

Hoffman, L. (1999). Marine cyanobacteria in tropical regions: Diversity and ecology. European Journal of Phycology, 34(4), 371-379.

Holmstrup, M., Costanzo, J. P., \& Lee, R. E. (1999). Cryoprotective and osmotic responses to cold acclimation and freezing in freeze-tolerant and freeze-intolerant earthworms. Journal of Comparative Physiology - B Biochemical, Systemic, and Environmental Physiology, 169(3), 207-214

Jensen, R. K., Rasmussen, J., \& Melander, B. (2004). Selectivity of weed harrowing in lupin. Weed Research, 44(4), 245-253.

Jimenez Aguilar, A., Huber-Sannwald, E., Belnap, J., Smart, D. R., \& Arredondo Moreno, J. T. (2009). Biological soil crusts exhibit a dynamic response to seasonal rain and release from grazing with implications for soil stability. Journal of Arid Environments, 73(12), 1158-1169.

Johnson, S. L., Neuer, S., \& Garcia-Pichel, F. (2007). Export of nitrogenous compounds due to incomplete cycling within biological soil crusts of arid lands. Environmental Microbiology, 9(3), 680-689.

Kalinichenko, A., Pisarenko, P., \& Kulyk, M. (2018). Algae in urban water bodies control of growth and use as a biomass. E3S Web of Conferences, 45, 00028.

Kang, L., Han, X., Zhang, Z., \& Sun, O. J. (2007). Grassland ecosystems in China: Review of current knowledge and research advancement. Philosophical Transactions of the Royal Society B: Biological Sciences, 362(1482), 997-1008.

Kezlya, E., Glushchenko, A., Maltsev, Y., Gusev, E., Genkal, S., Kuznetsov, A., Kociolek, J. P., \& Kulikovskiy, M. (2020). Placoneis cattiensis sp. nov. - a new, diatom (Bacillariophyceae: Cymbellales) soil species from Cát Tiên National Park (Vietnam). Phytotaxa, 460(4), 237-248.

Koffi, K., Philippe, K., Kouassi, A. M., Maryse, A. N., Kamanzi, K., \& Ama, A (2009). Seasonal distribution of phytoplankton in Grand-Lahou Lagoon (Côte d'Ivoire). European Journal of Scientific Research, 26, 329-341.

Komárek, J. (2013). Cyanoprokaryota. Part 3, Heterocytous Genera. Springer Spectrum, Heidelberg.

Komárek, J., \& Anagnostidis, K. (2005). Cyanoprokaryota. Part 2, Oscillatoriales. Springer Spektrum, Heidelberg.

Korotchenko, I., \& Peregrym, M. (2012). Ukrainian steppes in the past, at present and in the future. In: Werger, M. J. A. \& van Staalduinen, M. A. (Eds.). Eurasian steppes. Ecological problems and livelihoods in a changing world. Springer, Dordrecht. Pp. 173-196.

Krammer, K., \& Lange-Bertalot, H. (1986). Bacillariophyceae. 2/1. Naviculaceae. In: Ettl, H., Gerloff, J., Heynig, H., \& Mollenhauer, D. (Eds.). Süßwasserflora von Mitteleuropa. Gustav Fischer Verlag, Stuttgart, New York.

Krammer, K., \& Lange-Bertalot, H. (1988). Bacillariophyceae. 2/2. Bacillariaceae, Epithemiaceae, Surirellaceae. In: Ettl, H., Gerloff, J., Heynig, H., \& Mollenhauer, D. (Eds.). Süßwasserflora von Mitteleuropa. Gustav Fischer Verlag, Stuttgart, New York.

Krebs, C. J., Danell, K., Angerbjörn, A., Agrell, J., Berteaux, D., Bråthen, K. A., Danell, Ö., Erlinge, S., Fedorov, V., Fredga, K., Hjältén, J., Högstedt, G., Jónsdóttir, I. S., Kenney, A. J., Kjellén, N., Nordin, T., Roininen, H., Svensson, M., Tannerfeldt, M., \& Wiklund, C. (2003). Terrestrial trophic dynamics in the Canadian Arctic. Canadian Journal of Zoology, 81(5), 827-843.

Kulikovskiy, M. S., Maltsev, Y. I., Glushchenko, A. M., Gusev, E. S., Kapustin, D. A., Kuznetsova, I. V., Frolova, L., \& Kociolek, J. P. (2020). Preliminary molecular phylogeny of the diatom genus Nupela with the description of a new species and consideration of the interrelationships of taxa in the suborder Neidiineae D.G. Mann sensu E.J. Cox. Fottea, 20(2), 192-204.
Kulikovskiy, M., Kapustin, D., Glushchenko, A., Sidelev, S., Maltsev, Y., Gusev, E., Kezlya, E., Shkurina, N., Kuznetsova, I., \& Kociolek, P. (2020). Morphological and molecular investigation of Gomphonema longissimum and related taxa from Malili lakes (Indonesia) with comments on diatom evolution in ancient lakes. European Journal of Phycology, 55(2), 147-161.

Kulikovskiy, M., Maltsev, Y., Glushchenko, A., Kuznetsova, I., Kapustin, D., Gusev, E., Lange-Bertalot, H., Genkal, S., \& Kociolek, J. P. (2020). Gogorevia, a new monoraphid diatom genus for Achnanthes exigua and allied taxa (Achnanthidiaceae) described on the basis of an integrated molecular and morphological approach. Journal of Phycology, 56(6), 1601-1613.

Laamanen, M. (1996). Cyanoprokaryotes in the Baltic Sea ice and winter plankton. Algological Studies/Archiv Für Hydrobiologie, Supplement Volumes, 83, 423-433.

Lababpour, A. (2016). Potentials of the microalgae inoculant in restoration of biological soil crusts to combat desertification. International Journal of Environmental Science and Technology, 13(10), 2521-2532.

Lachashvili, N. J., Khachidze, M. N., Eradze, N. V., \& Khetsuriani, L. D. (2017). Steppe of Tbilisi environs (East Georgia, South Caucasus). Annals of Agrarian Science, 15(3), 332-338.

Langhans, T. M., Storm, C., \& Schwabe, A. (2009). Biological soil crusts and their microenvironment: Impact on emergence, survival and establishment of seedlings. Flora - Morphology, Distribution, Functional Ecology of Plants, 204(2), $157-168$.

Leßmeister, A., Bernhardt-Römermann, M., Schumann, K., Thiombiano, A., Wittig, R., \& Hahn, K. (2019). Vegetation changes over the past two decades in a West African savanna ecosystem. Applied Vegetation Science, 22(2), 230-242.

Liu, Q., Glushchenko, A., Kulikovskiy, M., Maltsev, Y., \& Kociolek, J. P. (2019). New Hannaea patrick (Fragilariaceae, Bacillariophyta) species from Asia, with comments on the biogeography of the genus. Cryptogamie, Algologie, 40(5), 41.

Liu, W., Xu, W., Hong, J., \& Wan, S. (2010). Interannual variability of soil microbia biomass and respiration in responses to topography, annual burning and $\mathrm{N}$ addition in a semiarid temperate steppe. Geoderma, 158(3-4), 259-267.

Liu, X., Hou, W., Dong, H., Wang, S., Jiang, H., Wu, G., Yang, J., \& Li, G. (2016). Distribution and diversity of Cyanobacteria and eukaryotic algae in QinghaiTibetan lakes. Geomicrobiology Journal, 33(10), 860-869.

López-Flores, R., Boix, D., Badosa, A., Brucet, S., \& Quintana, X. D. (2006). Pigment composition and size distribution of phytoplankton in a confined Mediterranean salt marsh ecosystem. Marine Biology, 149(6), 1313-1324.

Maar, M., Nielsen, T. G., Richardson, K., Christaki, U., Hansen, O. S., Zervoudaki, S., \& Christou, E. D. (2002). Spatial and temporal variability of food web structure during the spring bloom in the Skagerrak. Marine Ecology Progress Series, $239,11-29$.

Maestre, F. T., Huesca, M., Zaady, E., Bautista, S., \& Cortina, J. (2002). Infiltration, penetration resistance and microphytic crust composition in contrasted microsites within a Mediterranean semi-arid steppe. Soil Biology and Biochemistry, 34(6), 895-898

Mager, D. M., \& Thomas, A. D. (2011). Extracellular polysaccharides from cyanobacterial soil crusts: A review of their role in dryland soil processes. Journal of Arid Environments, 75(2), 91-97.

Mallin, M. A., \& Paerl, H. W. (1994). Planktonic trophic transfer in an estuary: Seasonal, diel, and community structure effects. Ecology, 75(8), 2168-2184.

Maltsev, Y. I., Maltseva, I. A., Maltseva, S. Y., \& Kulikovskiy, M. S. (2020). Biotechnological potential of a new strain of Bracteacoccus bullatus (Sphaeropleales, Chlorophyta) as a promising producer of omega- 6 polyunsaturated fatty acids. Russian Journal of Plant Physiology, 67(1), 185-193.

Maltsev, Y., \& Maltseva, I. (2018). The influence of forest-forming tree species on diversity and spatial distribution of algae in forest litter. Folia Oecologica, 45(2), $72-81$.

Maltsev, Y., Maltseva, I., Maltseva, S., Kociolek, J. P., \& Kulikovskiy, M. (2021a) A new species of freshwater algae Nephrochlamys yushanlensis sp. nov. (Selenastraceae, Sphaeropleales) and its lipid accumulation during nitrogen and phosphorus starvation. Journal of Phycology, 57(2), 606-618.

Maltsev, Y., Maltseva, S., Kociolek, J. P., Jahn, R., \& Kulikovskiy, M. (2021b). Biogeography of the cosmopolitan terrestrial diatom Hantzschia amphioxys sensu lato based on molecular and morphological data. Scientific Reports, 11, 4266.

Maltseva, I. A., \& Maltsev, Y. I. (2021). Diversity of cyanobacteria and algae in dependence to forest-forming tree species and properties rocks of dump. International Journal of Environmental Science and Technology, 18(3), 545-560.

Maltseva, I. A., Maltsev, Y. I., \& Solonenko, A. N. (2017). Soil algae of the oak groves of the steppe zone of Ukraine. International Journal on Algae, 19(3), 215-226.

Mamaeva, A., Namsaraev, Z., Maltsev, Y., Gusev, E., Kulikovskiy, M., Petrushkina, M., Filimonova, A., Sorokin, B., Zotko, N., Vinokurov, V., Kopitsyn, D., Petrova, D., Novikov, A., \& Kuzmin, D. (2018). Simultaneous increase in cellular content and volumetric concentration of lipids in Bracteacoccus bullatus cultivated at reduced nitrogen and phosphorus concentrations. Journal of Applied Phycology, 30(4), 2237-2246. 
Mata-González, R., Reed-Dustin, C. M., \& Rodhouse, T. J. (2018). Contrasting effects of long-term fire on sagebrush steppe shrubs mediated by topography and plant community. Rangeland Ecology and Management, 71(3), 336-344.

McGregor, G. B., Fabbro, L. D., \& Lobegeiger, J. S. (2007). Freshwater planktic Chroococcales (Cyanoprokaryota) from North-Eastern Australia: A morphological evaluation. Nova Hedwigia, 84(3), 299-331.

McLendon, T., \& Redente, E. F. (1992). Effects of nitrogen limitation on species replacement dynamics during early secondary succession on a semiarid sagebrush site. Oecologia, 91(3), 312-317.

Muñoz-Rojas, M., Lewandrowski, W., Erickson, T. E., Dixon, K. W., \& Merritt, D. J. (2016). Soil respiration dynamics in fire affected semi-arid ecosystems: Effects of vegetation type and environmental factors. Science of The Total Environment, 572, 1385-1394.

Mutalipassi, M., Mazzella, V., Romano, G., Ruocco, N., Costantini, M., Glaviano, F., \& Zupo, V. (2019). Growth and toxicity of Halomicronema metazoicum (Cyanoprokaryota, Cyanophyta) at different conditions of light, salinity and temperature. Biology Open, 8(10), bio043604.

Myers, P. E., \& Davis, J. S. (2003). Recolonization of soils by algae in a northcentral Florida pine forest after controlled fire and soil sterilization. Nova Hedwigia, 76(1), 207-219.

Nouwakpo, S. K., Williams, C. J., Pierson, F. B., Weltz, M. A., Kormos, P. R., Arslan, A., \& Al-Hamdan, O. Z. (2020). Effectiveness of prescribed fire to re-establish sagebrush steppe vegetation and ecohydrologic function on woodlandencroached sagebrush rangelands, Great Basin, USA: Part II: Runoff and sediment transport at the patch scale. Catena, 185, 104301.

Okello, W., Portmann, C., Erhard, M., Gademann, K., \& Kurmayer, R. (2009). Occurrence of microcystin-producing cyanobacteria in Ugandan freshwater habitats. Environmental Toxicology, 25(4), 367-380.

Okhapkin, A. G. (2015). The composition of Cyanoprokaryota in the plankton of Cheboksary reservoir (Nizhnii Novgorod, Russia). Algologia, 25(3), 265-277.

Olmstead, M. A., Wample, R., Greene, S., \& Tarara, J. (2004). Nondestructive measurement of vegetative cover using digital image analysis. HortScience, $39(1), 55-59$.

Ortega-Mayagoitia, E., Rojo, C., \& Rodrigo, M. A. (2003). Controlling factors of phytoplankton assemblages in wetlands: An experimental approach. Hydrobiologia, 502, 177-186.

Pełechata, A., Pełechaty, M., \& Pukacz, A. (2016). Factors influencing cyanobacteria community structure in Chara-lakes. Ecological Indicators, 71, 477-490.

Pinckney, J. L., Paerl, H. W., Harrington, M. B., \& Howe, K. E. (1998). Annual cycles of phytoplankton community-structure and bloom dynamics in the Neuse River Estuary, North Carolina. Marine Biology, 131(2), 371-381.

Pointing, S. B., \& Belnap, J. (2012). Microbial colonization and controls in dryland systems. Nature Reviews Microbiology, 10(8), 551-562

Prasse, R., \& Bornkamm, R. (2000). Effect of microbiotic soil surface crusts on emergence of vascular plants. Plant Ecology, 150, 65-75.

Rai, A. N. (Ed.). (2018). CRC Handbook of symbiotic cyanobacteria. CRC Press.

Rampelotto,P.H. (2013).Extremophiles and extreme environments. Life,3(3),482-485.

Rasmussen, I. A. (2004). The effect of sowing date, stale seedbed, row width and mechanical weed control on weeds and yields of organic winter wheat. Weed Research, 44(1), 12-20.

Reed-Dustin, C. M., Mata-González, R., \& Rodhouse, T. J. (2016). Long-term fire effects on native and invasive grasses in protected area sagebrush steppe. Rangeland Ecology and Management, 69(4), 257-264.

Reynolds, C. S. (1984). The ecology of freshwater phytoplankton. Cambridge University, Cambridge.

Richardson, K., Nielsen, T. G., Pedersen, F. B., Heilmann, J. P., Løkkegaard, B., \& Kaas, H. (1998). Spatial heterogeneity in the structure of the planktonic food web in the North Sea. Marine Ecology Progress Series, 168, 197-211.

Rivera-Aguilar, V., Godínez-Alvarez, H., Manuell-Cacheux, I., \& Rodríguez-Zaragoza, S. (2005). Physical effects of biological soil crusts on seed germination of two desert plants under laboratory conditions. Journal of Arid Environments, 63(1), 344-352.

Rodriguez-Caballero, E., Belnap, J., Büdel, B., Crutzen, P. J., Andreae, M. O., Pöschl, U., \& Weber, B. (2018). Dryland photoautotrophic soil surface communities endangered by global change. Nature Geoscience, 11(3), 185-189.

Samolov, E., Baumann, K., Büdel, B., Jung, P., Leinweber, P., Mikhailyuk, T., Karsten, U., \& Glaser, K. (2020). Biodiversity of algae and cyanobacteria in biological soil crusts collected along a climatic gradient in Chile using an integrative approach. Microorganisms, 8(7), 1047.

Savadogo, P., Diawara, S., Dayamba, S. D., Sawadogo, L., \& Nacro, H. B. (2017) Limited long-term effects of moderate livestock grazing and prescribed early fire on soil and root processes in Sudanian savanna-woodlands, West Africa. Geoderma, 306, 18-27.

Seger, C. D., Batista, A. C., Tetto, A. F., \& Soares, R. V. (2014). Fire behavior of prescribed burns in grass: Woody steppe on Paraná State, Brazil. In: Advances in forest fire research. Imprensa da Universidade de Coimbra. Pp. 234-243.
Shcherbyna, V. V., Maltseva, I. A., Maltsev, Y. I., \& Solonenko, A. N. (2017). Postpyrogenic changes in vegetation cover and biological soil crust in steppe ecosystems. Regulatory Mechanisms in Biosystems, 25(4), 633-638.

Shekhovtseva, O. G., \& Mal'tseva, I. A. (2015). Physical, chemical, and biological properties of soils in the city of Mariupol, Ukraine. Eurasian Soil Science, 48(12), 1393-1400.

Siebert, F., Klem, J., \& Van Coller, H. (2020). Forb community responses to an extensive drought in two contrasting land-use types of a semi-arid Lowveld savanna. African Journal of Range and Forage Science, 37(1), 53-64.

Sinetova, M. A., \& Los, D. A. (2016). New insights in cyanobacterial cold stress responses: Genes, sensors, and molecular triggers. Biochimica et Biophysica Acta-General Subjects, 1860(11), 2391-2403.

Smelansky, I. E., \& Tishkov, A. A. (2012). The steppe biome in Russia: Ecosystem services, conservation status, and actual challenges. In: Werger, M. \& van Staalduinen, M. (Eds.). Eurasian steppes. Ecological problems and livelihoods in a changing world. Plant and Vegetation. Springer, Dordrecht. Pp. 45-101.

Soares, M. C. S., Lürling, M., \& Huszar, V. L. M. (2013). Growth and temperaturerelated phenotypic plasticity in the cyanobacterium Cylindrospermopsis raciborskii. Phycological Research, 61(1), 61-67.

Stal, L. J. (2012). Cyanobacterial mats and stromatolites. In: Ecology of Cyanobacteria II: Their diversity in space and time. Springer Netherlands. Pp. 65-125.

Stavi, I. (2019). Wildfires in grasslands and shrublands: A review of impacts on vegetation, soil, hydrology, and geomorphology. Water, 11(5), 1042

Stred’anský, J., Lackóoá, L., Stred’anská, A., \& Varga, V. (2015). Determination of soil endangerment by wind erosion with consideration of legislative changes in acceptable soil loss. Ekologia, 34(1), 1-6.

Tang, S., Zhang, Y., Zhai, X., Wilkes, A., Wang, C., \& Wang, K. (2018). Effect of grazing on methane uptake from Eurasian steppe of China. BMC Ecology, 18(1), 11.

Tucker, C., Antoninka, A., Day, N., Poff, B., \& Reed, S. (2020). Biological soil crust salvage for dryland restoration: An opportunity for natural resource restoration. Restoration Ecology, 28(S2), S9-S16.

Ward, D. M., \& Castenholz, R. W. (2006). Cyanobacteria in geothermal habitats. In: Whitton, B. (Ed.). The ecology of cyanobacteria. Springer, Dordrecht. Pp. 37-59.

Warren, S. D., Rosentreter, R., \& Pietrasiak, N. (2020). Biological soil crusts of the Great Plains: A review. Rangeland Ecology and Management, in press.

Warren, S. D., St. Clair, L. L., Johansen, J. R., Kugrens, P., Baggett, L. S., \& Bird, B. J. (2015). Biological soil crust response to late season prescribed fire in a Great basin juniper woodland. Rangeland Ecology and Management, 68(3), 241-247.

Wesche, K., Ambarl, D., Kamp, J., Török, P., Treiber, J., \& Dengler, J. (2016). The Palaearctic steppe biome: A new synthesis. Biodiversity and Conservation, 25(12), 2197-2231

Whitton, B. A., \& Potts, M. (2006). Introduction to the cyanobacteria. In: Whitton, B. A., \& Potts, M. (Eds.). The ecology of cyanobacteria. Springer, Dordrecht. Pp. 1-11.

Zaitsev, A. S., Gongalsky, K. B., Persson, T., \& Bengtsson, J. (2014). Connectivity of litter islands remaining after a fire and unburnt forest determines the recovery of soil fauna. Applied Soil Ecology, 83, 101-108.

Zakhia, F., Jungblut, A. D., Taton, A., Vincent, W. F., \& Wilmotte, A. (2008). Cyanobacteria in cold ecosystems. In: Psychrophiles: From biodiversity to biotechnology. Springer, Berlin, Heidelberg. Pp. 121-135.

Zedler, P. H. (2007). Fire effects on grasslands. In: Plant disturbance ecology. Elsevier. Pp. 397-439.

Zerbo, I., Bernhardt-Römermann, M., Ouédraogo, O., Hahn, K., \& Thiombiano, A. (2016). Effects of climate and land use on herbaceous species richness and vegetation composition in West African savanna ecosystems. Journal of Botany, 2016, 1-11.

Zhang, Y. M., Wang, H. L., Wang, X. Q., Yang, W. K., \& Zhang, D. Y. (2006). The microstructure of microbiotic crust and its influence on wind erosion for a sandy soil surface in the Gurbantunggut Desert of Northwestern China. Geoderma, $132,441-449$.

Zhukov, O. V., Kunah, O. M., Dubinina, Y. Y., \& Novikova, V. O. (2018). The role of edaphic, vegetational and spatial factors in structuring soil animal communities in a floodplain forest of the Dnipro river. Folia Oecologica, 45(1), 8-23.

Zhukov, O. V., Kunah, O. M., Dubinina, Y. Y., Fedushko, M. P., Kotsun, V. I., Zhukova, Y. O., \& Potapenko, O. V. (2019). Tree canopy affects soil macrofauna spatial patterns on broad- and meso-scale levels in an Eastern European poplar-willow forest in the floodplain of the River Dnipro. Folia Oecologica, 46(2), 101-114.

Zhukov, O., Kunah, O., Dubinina, Y., Zhukova, Y., \& Ganzha, D. (2019). The effect of soil on spatial variation of the herbaceous layer modulated by overstorey in an Eastern European poplar-willow forest. Ekologia Bratislava, 38(3), 253-272.

Zhukov, O. V., Kovalenko, D. V., \& Maslykova, K. P. (2019). Physiognomic vegetation types and their identification by using the decryption of digital images. Agrology, 2(2), $94-99$. 